\title{
Review of:
}

\section{Allessandra Peri (ed.), M. Cornelii Frontonis Opuscula I: Arion - De feriis Alsiensibus, edizione critica e commento, Cassino 2004}

\author{
(Collana Scientifica 04 Studi archeologici, artistici, filologici, letterari e storici) Edizioni dell' \\ Università degli Studi di Cassino, ISBN 88-8317-022-9; XXVI,172 pp. [distribuzione: Viella Libreria \\ Editrice, Roma (viella@flashnet.it)]
}

\section{Text published in: Mnemosyne 60, 2007, 675-676}

The correspondence of Fronto, which had remained largely neglected for many years, recently regained some scholarly interest. The new Teubner edition (1988) and commentary by Van der Hout (1999) have been supplemented by other editions, notably the revised Italian UTET edition by Portalupi (1997) and a new Budé edition (2003) by Fleury and Demougin. I also mention a recent monograph by Christoph Tobias Kasulke (Fronto, Marc Aurel and kein Konflikt zwischen Rhetorik und Philosophie im 2. Jh.n.Chr., München-Leipzig 2005).

\begin{abstract}
One year earlier, another book was published concerning Fronto and his writings, in a series of studies published by the university of Cassino. The volume edited by Alessandra Peri focuses on textual criticism and on philologiocal explanations of Fronto's text. It contains a new critical edition of two, relatively short sections of the correspondence that may be considered rhetorical 'opuscula minora' by Fronto: the so called 'Arion', most likely a model text written for the young Marcus Aurelius, teaching him how to tell a good story in a terse style, and 'De feriis Alsiensibus 3', a letter to Marcus which takes the form of what is generally considered to be a programmatic speech in favour of literary studies, meant as an alternative for Stoic philosophy, that became ever more appealing to the young prince.
\end{abstract}

Fronto's letters are notoriously difficult to refer to, in the absence of one universally accepted system of numbering and subdivision. For the sake of convenience, I add the corresponding references to the edition of Van der Hout and to the widely used Loeb edition by Haines. The first fragment is Van den Hout p.241,1-242,10 (Haines I, p. 54-59), the second Van den Hout p. 227,5-233, 17 (Haines II, p. 4-19).

After a short introduction, which mainly deals with the history of the text of Fronto, transmitted in just one codex (Ambrosianus E 1476 sup., a palimpsest), and the aims of the present edition, Peri provides new critical texts of both fragments (p.5-29). Each page presents roughly 5 to 10 lines of Latin, followed by a double apparatus criticus. The first of these has readings presented by scholars who personally saw the palimpsest and reported the text of its first and second hands; the second apparatus contains only corrections and conjectures by later editors and commentators. The rest of the volume is devoted to a line to line commentary (p.33-163) and two short indexes (p.167-172). The notes are largely devoted to matters of textual criticism, and to lexicographical, syntactical, stylistical and historical details, interspersed with some observations on rhetorical strategy and literary aims.

The volume shows that a fresh look at the manuscript evidence of an ancient text is always worthwhile and can help to clarify difficult places in the traditional text. Peri has a keen eye for Fronto's partly eccentric style, and prints a text that shows some morphological particularities that tend to be smoothed away or avoided by other editors. To the average reader of Fronto, however, these textual minutiae will seem of relatively little relevance. I am not convinced that Peri's accurate and even painstakingly detailed approach (the texts in question have been subjected to a threefold process of collation) produces a Fronto text that is fundamentally better than any of the new editions mentioned above. Due to the special problems involved with the palimpsest and the damage it has incurred since it was first discovered in the 19th century, the constitution of Fronto's text will inevitably be a matter of debate forever.

The volume looks like a preliminary study that will ultimately lead to more editions of Frontonian texts. Given the quality of recent editions, it remains a question if all of Fronto is to be redone. By all means, a full edition along the lines of Peri's approach will be the scholarly work of a lifetime. But if new volumes are indeed to follow, the editor might consider adding translations of the Latin, as a practical tool for readers. 
